\title{
Preface, 2000: Lynn Revisited
}

This anniversary edition affords an opportunity to revisit an old haunt in nineteenth-century America after an absence of some twentyfive years. Although the shoe factories are all gone now, swallowed up by fire and urban sprawl, the story of the coming of industrial capitalism to an artisan town in New England remains a vital part of American history. As a microcosm of economic and social change during the Industrial Revolution, Lynn still has much to tell us about American development.

In many respects, the story appears similar to the original telling. It still revolves around the impact of the factory system on class relations, the sexual division of labor, and the tradition of "equal rights." But much has changed in the interim, and new perspectives have opened up since this book was first published in 1976. There are many tempting topics to choose from, including consumption, popular culture, and the law, but in these pages I will focus on three that have had a major impact on historical interpretation-gender, race, and globalization.

I cannot go any further without confessing to a bittersweet feeling involved in the whole business of looking backward. Sitting recently in the same room in the Lynn Historical Society where I had once spent a lot of research time, I picked up the same leather-bound volume of The $A w l$, the shoemakers journal from the 1840s, that I had read years ago, and, like Proust recalling his childhood, I was immediately transported back to that moment when the nineteenth century first began to reveal itself. There is no greater pleasure in historical research than the sense of transcending time by re-entering the past through the gateway of imagination. It is a kind of momentary victory over death, and here I was having that victory twice, at once going back to my younger research days and going back to the 1840 s. 
Part of the pleasure lay in remembering the heady atmosphere of the late 1960s, when social history was in its springtime. The social movements of that era-militant African-American struggles, antiwar agitation, a fledgling women's movement, stirrings of labor protest-were full of excitement and controversy, no matter what you thought about them. Emerging in loose kinship with these movements, social history had something of the feel of a movement itself, and the sense that making history and studying history went hand in hand left a powerful imprint on all who experienced it.

Adopting the vantage point of the anonymous many rather than that of the famous few, social historians probed American history "from the bottom up" with a critical eye not seen for decades. In witness to rapidly proliferating accounts of industrial workplaces, slave plantations, and immigrant communities, Eric Hobsbawm wrote in 1972, "It is a good moment to be a social historian."

The grandest aspiration was to capture the whole web of social relations in the great net of "total history." Slaves and workers were of interest for their own sake, of course, but we were on the lookout for the bigger fish of whole social systems, such as slavery and industrial capitalism. Industrial machinery, factory recruitment, and patterns of social mobility were explored in great detail with the ultimate goal of understanding the larger transformation of a commercial-agrarian society into an industrial one. For some, the Industrial Revolution was a step toward modernization; for others, it was a stage in capitalist development. Either way, the scale was large.

One of the most significant contributions of social history was to reinsert class into the lexicon of American history. Vaulting over consensus views that had dominated postwar historiography, social historians clasped hands with populists and progressives such as Charles Beard and Mary Beard, for whom economic conflict was the driving force of historical change. They also leaped across national boundaries to link up with the French Annales school and especially with British social historians, such as Edward Thompson, for whom class was more a lived experience of cultural antagonism than an economic or sociological category, but for whom Marx was never far from sight.

For an American like myself, coming upon class was something of a revelation. The idea that American development was driven at its deepest 
levels by antagonism between slave and master, wage earner and capitalist, consumer and multinational corporation had somehow gotten lost in the fog of myths about America as a classless society, or else obscured behind the curtain of ethno-religious pluralism. The belief that, at bottom, class was the key to inequality, that it was more important than money, merit, race, or any of the other usual suspects, was contrary to the conventional wisdom then and, even more so, now. Still, if I were to rewrite this book, I would modify my earlier view along the lines to be laid out in a moment, but I would not fundamentally change it.

Following Thompson into working-class culture, a good many American historians took labor republicanism to be a kind of homegrown class consciousness. My own variant of this theme was "equal rights," a vibrant popular tradition derived from the American Revolution that was used by working people, male and female, throughout the nineteenth century in defense of their interests. While not against private property or the market, the equal rights tradition was vehemently opposed to money-capitalists and industrial predators.

The theme of community is, no doubt, closer to American hearts than is class. Precisely because Americans live in a society where the centrifugal forces of the competitive market are so strong, the quest for community is especially intense. The more social history showed how individualistic Americans had been knit together, almost in spite of themselves, the more it gathered momentum in its depictions of the webs of social relations, whether in New England towns, slave communities, the bonds of womanhood, or the ties of ethnic kinship.

As part of that quest, many of us were drawn to the methodology of the community study. Inspired by such sociological classics as Middletown, we forged a long chain of community studies that stretched from the 1930s to dozens of examples in the 1970s and 1980s. The humble city of Lynn alone was the subject of no fewer than three other scholarly monographs. Everyone working on class and culture was indebted to the insights of Paul Faler; John Cumbler helped us all understand the importance of masculine leisure-time recreation in a comparison of Lynn and Fall River; and Mary Blewett, to be discussed shortly, brought gender into the picture. ${ }^{2}$

Community studies lived under the shadow of American exceptionalism. Even when they flatly rejected the assumption that the United States 
had escaped the ravages of European-style class division, they often addressed questions that fit within the exceptionalist framework, most famously, "Why is there no socialism in America?" This question was very much on my mind when I began looking at the politics of industrial workers in Lynn. There was no shortage of answers-high rates of mobility, ethnic heterogeneity, federalism, Americanism as surrogate socialism. My own preference was for the idea that the free gift of the ballot to white men had dampened their ardor for radical political change. In attempting to convey this view, I hit upon a metaphor that declared simply, "The ballot box was the coffin of class consciousness." This little phrase received more comment, not all of it favorable, than any other single point in the book.

If I had it to do over, I might be more careful to identify the corpse in the coffin as a major socialist party, but I am not inclined to retract the general assertion that access to voting rights for white men weakened radical political alternatives. Even so, I eventually came to believe that this was the right answer to the wrong question. The main trouble with "Why no socialism?" is that it asks about an absence, taking one pattern, chiefly Germany, to be the norm and the United States as a deviation. In a subsequent book entitled Struggles for Justice, I took pains to critique the whole exceptionalist framework.

Women (but not yet gender) were included in the agenda of the 1970s, often in association with resurgent "second-wave" feminism. Catching that wave, I examined the sexual division of labor between lady shoebinders and male bottomers, noted the subordination of women, and highlighted women's role in labor protest. Returning to Lynn to look once more at an illustration of the famous ladies' march during the great strike of 1860 (depicted on the cover of this book), I could not help reliving the initial excitement at coming upon the republican tradition of "equal rights" emblazoned on their banner: "American ladies will not be slaves."

Like the past itself, social history lives on in the present in many ways. It continues to influence much current work both directly and as a point of departure for all that has come since. Yet historical remembrance never repeats itself in exactly the same way, any more than history itself does, so asking new questions of the evidence will invariably produce a different picture of the past. 
So it was with the emergence of gender in the mid-1980s. It is impossible to return to Lynn without being curious about the difference gender makes. For example, what does it do to our picture of republicanism? In contrast to earlier studies, which had emphasized the positive influence of equal rights in struggles for women's rights, new works emphasized republican barriers to women's participation in the public sphere. What Joan Landes and Carol Pateman pointed out for Europe and Linda Kerber described for the era of the American Revolution was also true of nineteenth-century America. Republicanism was not merely defined without women; it was, in some respects, defined against them. That is, the formal public sphere of voting, representation, and decision-making was set aside as a male preserve because only men were thought to possess the independence and rationality necessary to exercise civic virtue. Women, by contrast, were economically dependent on their husbands and thought to be incapable of governing their emotions, so they were deemed unfit to govern others.

Applying the concept of gender to the same old dusty documents in the Lynn archives, Mary Blewett brought the shoemakers to life again as more complex human beings than they had earlier been portrayed. In Men, Women, and Work, she showed how different gender identities among women-as wives, home-based shoebinders, or factory "girls"-shaped the whole web of social relations from family life to the workplace and the public arena. For example, in the famous ladies' march during the great strike of 1860 , unity between male strikers and female binders, who sewed uppers at home, was achieved at the expense of single women who worked in proto-factories outside the family economy and whose wage demands were set aside. ${ }^{3}$

This altered the portrait I had drawn. Like most historians in the 1970s who paid attention to the sexual division of labor, I tended to see sexual difference in binary terms. Unintentionally imitating the nineteenth-century doctrine of "separate spheres," this view tended to attribute a false unity to each sex, just as contemporary supporters of the Equal Rights Amendment overestimated the degree of commonality among women, only to be surprised when many women defiantly raised the banner of homemaking and joined with male conservatives to defeat the amendment. 
Yet at a deeper level, Blewett's work and others like it remained very much in the vein of social history. ${ }^{4}$ It treated gender as an aspect of ideology linked to the material environment. Like their brothers in the Knights of St. Crispin, the male shoeworkers' union, the Daughters of St. Crispin "used the equal rights tradition to defend their interests." Different interests lent different meanings to the same set of republican ideals. To homeworkers, equality meant "separate spheres" for the two sexes, separate but equal; for factory girls, it meant equal pay for equal work. Similarly, different groups of women used republican values in different ways. While some emphasized feminine virtue, sought the respectability of republican motherhood, and eschewed the vote, others championed independence, sought equality in pay and politics, and supported equal suffrage. ${ }^{5}$

In most respects, I can only say "hurrah" to this work. It paints a fuller portrait than previous accounts, not just by adding more women (they had been there all along), but by showing how differences among women and between women and men shaped class relations and community life. Of late, cultural historians have pushed gender toward the study of identities, and have opened closet doors on lesbian and gay history to look, for example, at femininity and masculinity among gay men. ${ }^{6}$ It seems only a matter of time before these views are brought into the picture of New England mill towns. Such studies of gender vindicated social history by taking it in new directions.

At the same time, it is not clear how far gender identity will take us. Proposals to shift analysis from class to gender or to make cultural identity do most of the work of constructing the ladder of inequality seem to overreach the goal. It is one thing to point out how assumptions about women's subordination affected the creation of a dependent labor force, but another to leave property, technology, and wealth out of the equation.

Race is another topic that has received a great deal of attention over the past quarter-century. In the springtime of social history, Alexander Saxton argued in 1971 that native white workers in nineteenth-century California had seized upon Chinese immigrants as an "indispensable enemy" against whom they forged their own cohesive identity as workers in order to do battle with their employers. Expanding this analysis to include republicanism, Saxton went on to argue in later work that 
consciousness of being white was the main bridge linking Euro-American workers to the shifting political coalitions that ruled the republic. In a society divided by class, Saxton warned, democracy was likely to wind up being restricted to the herrenvolk, or master race. ${ }^{\text {? }}$

In a similar vein, other social historians were developing an understanding of race as an ideological feature of a class-divided society. Instead of using race to explain other things-slavery, poverty, backwardness-historians such as Edmund Morgan set out to explain race itself as a consequence of slavery, though it was nonetheless real for being a consequence. Pushing the analysis beyond the Civil War, Eric Foner, Ira Berlin, and the Freedom History Project showed how the racial politics of Reconstruction operated in a context of class conflicts arising from industrialization. Far from explaining other aspects of the social order, the very division of society into racial categories itself needed explaining. ${ }^{8}$

Linking race to republicanism, Barbara Fields argued that race became powerful in a slaveholding republic because it provided a way of reconciling the contradiction between egalitarian values and class inequality: "Racial ideology supplied the means of explaining slavery to people whose terrain was a republic founded on radical doctrines of liberty and natural rights." "It began to look as if racism was the ghost at the republican feast.

These historians helped raise understanding of race to a level of sophistication never before attained. Unlike the earlier generation of Progressive historians (W. E. B. Du Bois excepted), who had either slighted race (Beard) or treated it in biological terms, the race-as-ideology scholars pulled off the astounding feat of putting race at the forefront even while treating it as a consequence of deeper social and economic forces.

Unfortunately, this approach bypassed New England. To date, there has been no significant work on New England mill towns with race as a central theme. Completely absent from Blewett and Cumbler, racism is mentioned only fleetingly in Faler and in my own book. Attitudes toward slaves and antislavery agitation receive somewhat more coverage, but even there race is secondary to political ideas. For my part, I took the virtual absence of evidence of overt racial conflict in the sources I used-newspapers, local histories, city 
directories, manuscript censuses-as warrant to give the subject only limited attention. I also believed then that local circumstances pushed race to the margins of everyday life; after all, the population was overwhelmingly of European descent and the burden of racial exclusion was borne by a tiny minority.

It is not that I thought racism was unimportant in the larger scheme of things. To the contrary, as a veteran of the civil rights movement in Mississippi, where I had edited the Mississippi Free Press in 1963-1964, and as a sympathizer with black power, I was acutely aware of the significance of racial matters. Exposure to the depth of racial oppression in the Deep South was what opened the door for me to see class and other kinds of oppression in the first place. Some of the most exciting work was being done in fields in which race was key-slavery, urban life, African-American studies-and I followed it with great interest. But it seemed to be running on a parallel track.

Recently, studies of "whiteness" in Euro-American communities have brought race to the forefront. Drawing on Saxton, historians such as David Roediger and Noel Ignatiev attempted to show how native and immigrant workers alike "became white" in order to obtain the psychological and material advantages of being a superior race in a classdivided society. To appreciate fully the process of class formation in a society undergoing industrialization, they argued, it is essential to locate that process within a slaveholding republic. In their view, wage earners were driven by their "fear of dependency on wage labor" and their opposition to "the necessities of capitalist work discipline" to wrap themselves in the color of privilege. ${ }^{10}$ The most radical idea was the assertion that racial identity arose directly from class experience. This was a stunning turnabout in the understanding of class. Rather than pointing toward transracial solidarity, the logic of class was now said to point in exactly the opposite direction, toward racial polarization.

Republicanism was turned upside down at the same time. Drawing on theories of symbolic representation, some scholars argued that far from being color-blind, republicanism was deeply color-conscious. In the moral universe of the "producing classes," all the virtues of freedom, independence, and self-discipline were coded white; conversely, all the vices of degradation, servility, and dependence were coded black or yellow. If gender pointed toward an ambivalent view of 
republicanism, the analysis of "whiteness" ended in a completely pessimistic view: in the American context, working-class experience generated a white identity that blanketed republicanism to the point of ruling out transracial solidarity.

In the Janus face of race in America, whiteness was paired with its polar opposite. According to Robin Kelley, "black working people struggled to maintain and define a sense of racial identity and solidarity" by rallying to Marcus Garvey's race pride and Malcolm X's black power. Even while acknowledging that race was thoroughly entangled with class, Kelley contended that overt expressions of resistance normally demonstrated "the centrality of race in the minds and experiences of African-Americans." ${ }^{11}$

By the late 1990s, three things were clear. Race had displaced class at the center of attention; race was seen more in terms of cultural identity than in terms of ideology; and, as such, it was more cause than consequence. That is, instead of being seen as an ideological consequence of other forces, racial identity was increasingly used as the key factor in explaining inequality. ${ }^{12}$

Reconsidering accounts of transracial success in the 1930s, some historians came to focus, instead, on the deep attachment of (white) industrial workers to assumptions about white men's jobs at white men's wages, privileges they were ready to defend through "hate strikes," riots, or any other means. Although some historians went so far as to abandon labor subjects altogether, shifting their categorical sights from class to race, others showed how race trumped class. One rather polemical example did not hesitate to explain the whole sweep of American politics in terms of shifting coalitions built around white supremacy that succeeded at every critical juncture-the Revolution, Reconstruction, the New Deal-in dividing and conquering the working class. ${ }^{13}$ It began to look like American exceptionalism all over again, with race as a kind of original sin that barred the way to labor unity, socialism, and a strong welfare state.

The shift to race was simultaneously taking place in other disciplines as well. Racial explanation moved to the foreground, for example, in sociological studies of "American apartheid" and the American dream. Two sociologits put forward a model of "racial formation" in which they asserted that race in the United States 
should be treated as "a fundamental organizing principle of social relationships." Following in these footsteps, one historian of nineteenth-century California concluded that the social order was "a hierarchy of group inequality in which race, not class, became the central stratifying variable." ${ }^{14}$

The idea of racial formation had strong affinities with cultural interpretations of identity. For help in overthrowing biological explanations of racial difference, cultural historians turned to postmodern philosophers such as Cornel West, who repudiated "racial reasoning" in favor of explanations that favored cultural construction. Michel Foucault's ideas about discourse-our deepest beliefs and assumptions-were especially influential in moving us away from the concept of ideology, which had located race within a matrix of specific material conditions, socioeconomic structures, and political institutions, toward the notion of identity and other cultural forms as the primary influences in the constitution of social organization. ${ }^{15}$

It should be noted that many, perhaps most, historians of race and labor did not go down the path of cultural construction. Those who remained social historians at heart grounded their analysis in material conditions and tried to balance the claims of class and race in concrete historical settings from Chicago packinghouses and Detroit neighborhoods to the southern factories after World War II. The fact that interracial unionism was possible in some of the most unlikely bastions of segregation such as Memphis mills, Alabama coal regions, and New Orleans docks showed that race did not always trump labor solidarity. ${ }^{16}$ Even so, the racial aspects of capitalist society loom a good deal larger than they did a quarter-century ago.

As with gender, it is impossible to return to Lynn without being curious about the difference race makes. To reread the same scratchy microfilm of the Little Giant, a labor-reform paper from the $1870 \mathrm{~s}$, with eyes open to racial matters, is, in some sense, to read it for the first time. Racial aspects overlooked by all of Lynn's historians now come readily into view. Denouncing Chinese labor as "an unmitigated pest," the Little Giant anointed the importation of Chinese workers to break a strike at a shoe factory in North Adams, Massachusetts, as one of the two most important events of 1870 . The other was a dispute involving the shoeworkers' union the Knights of St. 
Crispin. Clearly, there was a close association between anti-Chinese sentiment and labor organizing, even where the Chinese were a tiny fraction of the work force.

To further explore linkages between class and race, it is worth quoting at length from an 1871 editorial in the Little Giant:

Human muscle has always been the cheapest thing in the market: and its purchasers have ever been striving to "bear" down its value. The cupidity of man enslaves other men, and unfortunately it is often aided in so doing by those who wield an influence through the press. The Chinaman is popular with many because he is cheap; because he will work for nothing and board himself; because he is ignorant, and submissive to his master; because he claims no rights, and has no manliness to stand up for that which is his own. ${ }^{17}$

Accepting human cupidity as a given, the editor lays ultimate blame upon the greedy purchasers of labor for attempting to "enslave" other men. Elsewhere, the same paper equated the importation of contract labor with "a new system of slavery," noting that "the motives which actuate those who import Coolies under the contract system are born of the same mother that negro slavery was." The consequence of this ill treatment is the degradation of labor-slaves and "coolies" alike-to the status of cheap, ignorant, and submissive creatures. Class analysis could hardly have been more explicit.

Yet in apportioning a share of the blame to the Chinese themselves, the reasoning turns racial. The Chinese are seen to possess inbred vices that make them "extremely filthy, licentious and dishonest." Unlike white men, they lack race pride. They are inherently submissive and incapable of claiming their rights because-here the reasoning turns to gender-they also lack that essential quality of honest labor: manliness. Because women were expected to submit to male authority, effeminacy in men is a sure sign of subordination. ${ }^{18}$ For insights on the ways class, race, and gender constructed one another, we are indebted to theories of discourse.

Yet caution is in order. To ask about white identity is to ask a "yes" question. Did Euro-American workers perceive people in terms of black and white, "them" and "us"? Yes, they did, and they sought to exclude blacks (and women) from what they regarded as white men's jobs. But then to ask whether maintaining their "whiteness" precluded support for 
the emancipation of slaves is to get a different answer. The Awl was full of enthusiastic reports of antislavery meetings, including an 1844 rally to give "that eloquent representative of the slave, Frederic Douglass," and other local luminaries a big send-off before they left for England. ${ }^{19}$

The fact that Douglass worked for a time as a shoemaker in Lynn did not mean that free blacks received red-carpet treatment, any more than sympathy for slaves translated into solidarity with black workers. But readers of The $A w l$, as well as the rest of the local press during the Civil War and after, will search in vain for accounts of race riots and mob attacks on the small black population that resided in the city. In the 1880s, Lynn voters even sent an African American to city council. Apparently, at least some northern industrial workers did not work as hard as expected at maintaining their "whiteness."

To be sure, there were other arenas besides race riots for the performance of white identity. According to Eric Lott, none is more important than blackface minstrelsy. The white mechanics and laborers who put on burnt cork and cavorted onstage as the plantation slave Jim Crow or the dandified free black Zip Coon were engaged in a many-layered ritual in which they simultaneously mocked the racial "other" and yet displayed nostalgia for the easygoing preindustrial way of life that he (and sometimes "she," in drag) represented. ${ }^{20}$ What seems merely grotesque today once had more subtle meanings.

Did Lynn shoemakers patronize minstrel shows? Again, yes. In the same issues of the Little Giant that castigated "coolie" labor, there were notices for the performance of a large troupe of "the delineators of negro character." 21 But whether "blacking up" was an outgrowth of the class experience of workers is another question. As with boxing, blood sports, and other male entertainment, nineteenth-century audiences often crossed class lines. In Lynn, for example, minstrelsy was taken up by the local gentry. The Oxford Club, founded in the 1880s and open only to successful business and professional men, staged regular minstrel shows as charity events to benefit the local hospital and old ladies' home. Accompanied by the Coon Town Orchestra, some of Lynn's finest put on burnt cork and women's clothes and went through the comic gyrations of "Aunt Jemima's Jubilee." ${ }^{22}$ At the very least, such evidence calls into question the claim that whiteness is the product of working-class experience. 
What, then, was the role of white identity among nineteenth-century industrial workers? Much of the attention has focused on Irish laborers, since they were closest to blacks in neighborhood and occupation and, therefore, had the most to gain, in the short run, by elevating their status through membership in a putative superior race. Irish hostility to African Americans was expressed in such well-known episodes as the Civil War antidraft riot of 1863 , which involved murderous rampages against black New Yorkers.

Yet it is worth asking whether it was whiteness for which the Irish poor were contending. It seems more likely that racial claims operated in a sociopolitical context in which other factors weighed at least as heavily in the balance. That is the contention of Jacqueline Jones in American Work, which shows how the Irish were able to outmuscle African Americans not just because of their white identity, but because they could muster more economic and political resources-Irish kinship networks led to jobs; concentration in certain jobs made for economic strength; sheer numbers translated into political clout through the pro-immigrant, racist Democratic party. ${ }^{23}$

As this analysis suggests, identities are always connected in one way or another to the larger matrix of social, economic, and political power. Differences between "us" and "them" are played out along the vertical axis of who rules whom. It may be that the cultural process of "making whiteness" is worth the attention it has received of late, but unless that process is connected to the complex nexus of social inequality - and the accompanying clash of economic and political interests-it quickly runs out of analytical steam. ${ }^{24}$ It remains to be seen how identity and power played out in New England mill towns. Where Irish and other European immigrants were numerous, but where potential AfricanAmerican or Asian competitors were few, was the color line as important as it was in great port cities like New York? How did the pattern of racial exclusion in northern industrial cities compare with southern segregation? It would be interesting to find out.

Another set of questions at the dawn of the twenty-first century derives from globalization. With the end of the Cold War and the collapse of the Soviet Union, it seemed as if nothing could stop the juggernaut of global capitalism. Vaulting over national and political barriers, transnational corporations spread their production chains, telecommunication networks, 
and marketing operations to the four corners of the earth, in the process creating not one uniform world, but a heterogeneous agglomeration of low-wage producers living in shantytowns far removed from affluent consumers in gated developments on the opposite side of the global tracks.

As a result, economic questions returned to center stage. New work has appeared on the swirling flows of commodities, labor, and forms of knowledge around the globe. Despite, or perhaps because of, the demise of Marxist officialdom, capitalism has come back into view, often with the neoliberal banners of free-market philosophy waving high. In other cases, capitalism keeps company with more critical ideas about the "world system" and the way the economy is "embedded" in society. After twenty years of ascendancy, there is growing reaction against high literary theory and the "poststructuralist" cultural history associated with it; and there is a strong impulse, not least among historians of culture, to link symbolic representation to material conditions, economic interests, and the distribution of wealth and power.

Someone beginning work anew on a medium-sized industrial community in nineteenth-century New England will likely want to pose questions about the international economy. Tracking down answers will require some scholarly globetrotting--perhaps a visit to the western frontier, where new markets for shoes and textiles emerged in expanding white settlements, whose run-ins with Indians were followed closely back East. Whereas the attitudes of eastern elites such as Teddy Roosevelt are well known, there is less understanding of the ways in which the Indian Wars shaped working people's sense of themselves as white Americans.

A few paths to the wider world have already been marked out. These include international labor migration, especially from Ireland and other European locations, and international capital flows, chiefly from the City of London. But other uncharted pathways of trade and migration ran into the Deep South and into South America, where there were important markets and sources of raw materials. To recognize the presence of southern plantations and South American cattle ranches in the larger web of transnational economic relations in which New England was also enmeshed is to view African and Latin workers as indirect stakeholders in the system.

Our globe-trotting historian should not overlook the century-long 
abolition of slavery throughout the Western Hemisphere, which set agricultural employers on a search for other sources of cheap, coerced labor that led them as far afield as China. To understand how Chinese laborers wound up in a North Adams, Massachusetts, shoe factory-not to mention New York cigar shops, Rocky Mountain railroad tunnels, and Hawaiian pineapple plantations-it will be necessary to look at events that never used to register on the seismometers of New England history, such as China's Taiping Rebellion, which sent great numbers of migrant laborers on a trek to the New World. Because shock waves rippled out across the globe, these events, in some sense, happened in New England, and dissertations are waiting to be written that will explain how.

In adopting this wider angle, we should not allow the local setting to slip out of focus. In the end, the historical actors are real people enmeshed in actual social relations and engaged in observable social practices that leave detectable tracks in the historical record. In leaving their footprints in the snow that blustery March morning in 1860, the lady shoebinders of Lynn who raised the banner of equal rights were making history out of everyday materials close at hand. Like seamstresses stitching together the billowy dresses they donned for the occasion, they combined womanly virtue, Yankee self-respect, and republican ideals in proclaiming their refusal to be treated like slaves. However homespun their banner, it is important to see it as a local response to slavery, industrial capitalism, and other world historical developments. More than ever, we need to see the global in the local, or, after Dylan Thomas, "to see the round Zion of the water bead, the synagogue in the ear of corn."

Looking at the local community as a microcosm of large-scale processes reaffirms the founding impulse of social history. The affinity between global history and what used to be known as total history is marked by the common goal of understanding what Raymond Williams called the "indissoluble connections" among cultural symbols, social relations, and economic structures. If cultural history stretched those connections almost to the breaking point, the original impulse is now coming back into view. Provided that it is held up as an ever-receding goal, not a fixed endpoint, seeking interconnections is a worthy pursuit.

To suggest that globalization is drawing attention to the big picture again is not to say that we should go back to the social history of the 1970 s, even if we could, or that the contributions of cultural history in the 1980s and 1990s should be set aside. To the contrary, historians will 
surely want to keep cultural factors in view. In reconnecting, once again, to the progressive current in American scholarship represented by the Beards, it would be foolish to repeat the mistake of seeing "economic man"-and a white one, at that-as the main historical actor. The movement should be a spiral, not a circle.

All the same, perhaps the vision of wholeness and cohesion-the quest for community writ large in a fragmented, alienated, class-divided world-is not really outdated after all. One day, historians will return to the nineteenth-century world with some semblance of this vision and will write new stories accordingly. When that happens, the result will be a twice-told tale about the struggles of ordinary folk in kitchens and workshops to take control of their own destiny in the face of superior forces arrayed against them. In the meantime, the present tale will have to stand. I have left the following text just as it was a quarter-century ago in hopes that it might continue to speak to contemporary concerns.

\section{Notes}

I would like to thank Ken Turino, Director, and the staff of the Lynn Historical Society for help in locating materials.

1. Eric Hobsbawm, On History (New York, 1997; orig. ed. 1972), p. 93.

2. Paul Faler, Mechanics and Manufacturers in the Early Industrial Revolution: Lynn, Massachusetts, 1780-1860 (Albany, 1981); John Cumbler, Working Class Community in Industrial America: Work, Leisure, and Struggle in Two Industrial Cities, 1880-1930 (Westport, Conn., 1979); Mary Blewett, Men, Women, and Work: Class, Gender, and Protest in the New England Shoe Industry, 1780-1910 (Urbana, 1988).

3. Blewett, Men, Women, and Work, pp. 118-141.

4. Mary Ryan, Cradle of the Middle Class: The Family in Oneida County, New York, 1790-1865 (Cambridge, Eng., 1981); Christine Stansell, City of Women: Sex and Class in New York (New York, 1986); Ruth Milkman, Gender at Work: The Dynamics of Job Segregation by Sex during World War II (Urbana, 1987); Ava Baron, ed., Work Engendered: Toward a New History of American Labor (Ithaca, 1991).

5. Blewett, Men, Women, and Work, p. 191.

6. George Chauncey, Gay New York: Gender, Urban Culture, and the Making of the Gay Male World, 1890-1940 (New York, 1994).

7. The pioneering nature of Saxton's work is evident in the publication date of The Indispensable Enemy: Labor and the Anti-Chinese Movement in California (Berkeley, 1971); Alexander Saxton, The Rise and Fall of the White Republic: Class Politics and Mass Culture in Nineteenth Century America (London: Verso, 1990), pp. 13-18. For parallel arguments, see Thomas D. Boston, Race, Class, and 
Conservatism (Boston, 1988); David T. Wellman, Portraits of White Racism (Cambridge, Eng., 1993), 2d ed. On capitalist development, see Stanley Greenberg, State and Race in Capitalist Development: Comparative Perspectives (New Haven, Conn., 1980).

8. Edmund Morgan, American Slavery/American Freedom: The Ordeal of Colonial Virginia (New York, 1975); the many studies by Eugene Genovese, especially Roll, Jordan, Roll: The World the Slaves Made (New York, 1974); Eric Foner, Reconstruction: America's Unfinished Revolution, 1863-1877 (New York, 1988); Ira Berlin et al., eds., Freedom: A Documentary History of Emancipation (New York, 1982).

9. Barbara Fields, "Slavery, Race and Ideology in the United States of America," New Left Review 181 (May/June 1990), 95-118; quote on p. 114. The paradox of racial inequality emerging from egalitarian ideology is compared to the Hindu caste system in Louis Dumont, Homo Hierarchicus: An Essay on the Caste System, trans. M. Sainsbury (Chicago, 1970).

10. David Roediger, The Wages of Whiteness (London, 1991), p. 13; Noel Ignatiev, How the Irish Became White (New York, 1995). See also Theodore Allen, The Invention of the White Race (New York, 1994).

11. Robin D. G. Kelley, Race Rebels: Culture, Politics, and the Black Working Class (New York, 1994), p. 5; Kelley, "We Are Not What We Seem': Rethinking Black Working Class Opposition in the Jim Crow South," Journal of American History 80 (June 1993), 75-112; Kelley, Yo' Mana's Disfunktional! Fighting the Culture Wars in Urban America (Boston, 1997).

12. Race has become a staple of debate in the field of labor history, where review essays include Eric Arnesen, "Up from Exclusion: Black and White Workers, Race, and the State of Labor History," Reviews in American History 26 (1998), 146-174; Herbert Hill, "The Problem of Race in American Labor History," Reviews in American History 24 (1996), 180-208; Alan Dawley and Joe Trotter, "Race and Class," Labor History 35 (Fall 1994), 486-494.

13. For a reconsideration, see Bruce Nelson, "Class, Race and Democracy in the CIO: The 'New' Labor History Meets the 'Wages of Whiteness,"' International Review of Social History 41 (1996), 351-374. The shift to race is evident in two publications by Nick Salvatore, Eugene V. Debs: Citizen and Socialist (Urbana, 1982) and We All Got History: The Memory Book of Amos Weber (New York, 1996). The polemic is Michael Goldfield, The Color of Politics: Race and the Mainsprings of American Politics (New York, 1997).

14. Douglas Massey and Nancy Denton, American Apartheid: Segregation and the Making of an Underclass (Cambridge, Mass., 1993); Jennifer Hochschild, Facing Up to the American Dream (Princeton, N.J., 1995); Michael Omi and Howard Winant, Racial Formation in the United States: From the 1960s to the 1980s (New York, 1986), p. 66, ital. in original; Tomas Almaguer, Racial Fault Lines; The Historical Origins of White Supremacy in California (Berkeley, 1994), p. 12.

15. Cornel West, Race Matters (Boston, 1993), chap. 2, "The Pitfalls of Racial Reasoning." Stuart Hall, for example, may have retained the view that "events, relations, structures do have conditions of existence and real effects outside the sphere of 


\section{xxviii PREFACE, 2000: LYNN REVISITED}

the discursive." However, following Foucault, Hall began to lay greatest stress on discourse: "This gives questions of culture and ideology, and the scenarios of representation-subjectivity, identity, politics-a formative, not merely an expressive, place in the constitution of social and political life." Stuart Hall, "The New Ethnicities," in James Donald and Ali Rattansi, eds., "Race," Culture, and Difference (Newbury Park, Calif., 1992), pp. 253-254. For an earlier emphasis on the "dialectic between conditions and consciousness," see Hall's 1980 essay "Cultural Studies: Two Paradigms," in Nicholas B. Dirks, Geoff Eley, and Sherry B. Ortner, eds., Culture/Power/History: A Reader in Contemporary Social Theory (Princeton, N.J., 1994), pp. 520-538.

16. Daniel Letwin, The Challenge of Interracial Unionism: Alabama Coal Miners, 1878-1921 (Chapel Hill, 1998); Rick Halpern, Down on the Killing Floor: Black and White Workers in Chicago's Packinghouses, 1904-54 (Urbana, 1997); Roger Horowitz, "Negro and White, Unite and Fight!": A Social History of Industrial Unionism in Meatpacking, 1930-90 (Urbana, 1997); Thomas Sugrue, Origins of the Urban Crisis: Race and Inequality in Postwar Detroit (Princeton, N.J., 1996); Michael Honey, Southern Labor and Black Civil Rights: Organizing Memphis Workers (Urbana, 1993); Eric Arnesen, Waterfront Workers of New Orleans: Race, Class, and Politics, 1863-1923 (Albany, 1988); Bruce Nelson, Workers on the Waterfront: Seamen, Longshoremen, and Unionism in the 1930s (Urbana, 1988). For a different view that argues the essential racism of the AFL, see Gwendolyn Mink, Old Labor and New Immigrants in American Political Development: Union, Party, and State, 1875-1920 (Ithaca, 1986).

17. Little Giant, April 29, 1871; Dec. 31, 1870.

18. Little Giant, Nov. 3, 1870; April 15, 1871.

19. The Awl, Aug. 23, 1844.

20. Eric Lott, Love and Theft: Blackface Minstrelsy and the American Working Class (New York, 1993).

21. Little Giant, Dec. 24, 1870.

22. Oxford Club materials from 1883 through the early 1920 s are in the Lynn Historical Society.

23. Jacqueline Jones, American Work: Four Centuries of Black and White Labor (New York, 1998), pp. 276-297.

24. In addition to previously noted works by Roediger, Ignatiev, Allen, and Jacobson, see also Grace Hale, Making Whiteness: The Culture of Segregation in the South, 1890-1940 (New York, 1998); Paul Gilroy, Against Race: Imagining Political Culture beyond the Color Line (Cambridge, Mass., 2000).

25. Dirk Hoerder, Cultures in Contact: European and World Migrations, 11th c. to the 1990s (Durham, N.C., 2000); John Gray, False Dawn: The Delusions of Global Capitalism (New York, 1998); Richard Barnet and John Cavanagh, Global Dreams: Imperial Corporations and the New World Order (New York, 1994); Immanuel Wallerstein, The Modern World System, 3 vols. (New York, 1974-1988); Eric Wolf, Europe and the People without History (Berkeley, 1982); Karl Polanyi, The Great Transformation (Boston, 1944); Sidney Mintz, Sweetness and Power: The Place of Sugar in Modern History (New York, 1985). 


\section{CLASS AND COMMUNITY}

THE INDUSTRIAL REVOLUTION IN LYNN 
